\title{
ANDREW MARTINDALE
}

On 16 October 1994, in what was to be the last research seminar he presented in the School of World Art Studies at the University of East Anglia, Andrew Martindale addressed assembled colleagues and graduate students on one of the aspects of medieval palace decoration which had recently being occupying his thoughts, the choice of heroes (and sometimes heroines too) represented in sculpture, painting, or tapestry in the great halls and chambers of the fourteenth and early fifteenth centuries. His title was 'Let us now praise famous men' (Ecclesiasticus 44.1), though by one of those quirks of mistranscription it appeared on the schedule that was sent out to advertise the event as 'Let us now praise funny men'.

Andrew himself could be wonderfully witty, but his own claim to a place in the hall of fame rests largely upon the quality of his scholarship. By that I do not mean simply that he could be trusted to get things right, but that at the root of his life as an academic was a series of perceptions and beliefs which help to justify (and, sadly, it seems increasingly to need justifying) the expression 'the humanities' to encompass the study of art, music, literature, and history. There are many passages from his published writings which proclaim these values, but as these are generally available and because his voice is perhaps more clearly to be heard in a semi-formal context, I would like to quote from his inaugural lecture, on Andrea Mantegna, given in 1974.

I am a firm believer in the central importance of the human imagination - both as the subject of study of the art historian and as the most significant single virtue in the writing of history. Of course, all the historical techniques which one learns are indispensable; and the duties of the historian include all the chores of checking, transcribing, setting out in order and a hundred and one other things. But in the end ... the choice between the 


\section{T. A. HESLOP}

work as a whole receiving the breath of life or the kiss of death will depend upon imagination.

He continued: 'If I had given you a sermon tonight it would have been just this - history and imagination.'

There are a number of ideas in this short extract which speak volumes about Andrew as an academic and as a person. The words 'believer', 'virtue', 'duties', 'life', 'death', and 'sermon' all have strong religious and, in his case, Christian overtones. But the central concept is that of making the past live through a combination of carefully checked data and the historian's imaginative process. The past lives through the people who inhabited it. Their thoughts can be accessed through what they wrote or what is otherwise recorded about them, but for the art historian they are primarily accessible through imagery.

In his writings and through his teaching Andrew brought the past before the eyes of the present as an invigorating and stimulating set of exempla, generally singling out things which were case studies but were also paradigmatic. As a colleague too he worked by example. For much of the day he was to be seen at the further end of his glass-fronted office sitting at his desk like some fifteenth-century image of Jerome in his study, or talking to students or staff, singly or in groups. He was least happy in committees or responding to reports or memoranda - and there too he had a significant influence on those around him. The School of World Art Studies over which he presided for over two decades is still pervaded by a tendency to avoid bureaucracy.

His own inclinations helped to make us 'able ministers not of the letter but of the spirit' ('for the letter killeth but the spirit giveth life'). But despite his preferences for dealing with things on a personal level and trusting individuals to make wise decisions and act accordingly, Andrew's own sense of duty led him to devote a good deal of his time to serving on UGC and UFC committees, on the Council for the Care of Churches, and latterly as the Chairman of the Norwich Cathedral Fabric Advisory Committee. That sense of duty and his caring - about things, people, and the past inevitably triumphed over reluctance to take on yet more 


\section{Andrew Martindale}

work. In the end it was this caritas that underlay his actions both public and private: his humour and hospitality as much as his research and administration. We shall all miss him, whether as colleague, friend, scholar, or wise counsellor. But he will live in our memories and through his teaching and writing, and I am sure that these are the halls of fame which are the most appropriate monument to a lovely man.

T. A. Heslop

Dean of the School of World Art Studies

University of East Anglia 